\title{
A Case Report of a Proactive Approach to Perioral Reconstruction After Severe Dog Bite Injury
}

\section{Köpek Isırığına Bağlı Şiddetli Ağız Çevresi Yaralanmasının Erken Evre Tedavisi: Vaka Sunumu}

Kamil F. Abdullaev ${ }^{1}$ Evgeniy A. Vasilyev², David L. Safaryan ${ }^{1}$, Ekaterina V. Orlova ${ }^{3}$, Manish K. Yadav ${ }^{1}$, Mikhail N. Bolshakov ${ }^{1}$

${ }^{1}$ Department of Oral and Maxillofacial Surgery at Central Research Institute of Dentistry and Maxillofacial Surgery. Moscow, Russia.

${ }^{2}$ Maxillofacial Hospital for War Veterans. MHD. Moscow, Russia.

${ }^{3}$ Federal Scientific and Clinical Center of Otorhinolaryngology of Federal Medicine and Biological Agency. Moscow, Russia.

Geliş Tarihi/Received: 17 February 2019 Kabul Tarihi/Accepted: 9 March 2019

Address correspondence to: Kamil Firudinovich Abdullaev, Mira str, building 6, app. 24, Volgograd city, Russia. 400066 e-mail: drabdullaevkamil@gmail.com

\begin{abstract}
Öz
Yüz bölgesinde meydana gelen hayvan ısırıkları ciddi defektlere yol açabilir. Kısıtlı vakalarda kopmus parça iyi saklandığı ve hastayla beraber getirildiği takdirde en iyi çözüm replantasyondur. Kalan vakalarda birkaç tedavi yöntemi kullanılmaktadır. Klasik bir tedavi yöntemi olarak "tetikte bekleme" stratejisi, yaranın kendiliğinden iyileşmesine izin vermek ve ancak öyle rekonstrüksiyona başlamak olarak tarif edilebilir. Fakat iyileşmenin erken döneminde ileriye dönük rekonstrüksiyonu başlatmak, hızlı rehabilitasyonu sağlamaktadır. Bu çalışmada genç bir kızda köpek ısırığı sonrası perioral bölgede gelişen defektin erken dönemde başarılı rekonstrüksiyonu ayrıntısıyla tarif edilmiştir. Rekonstrüksiyonda anatomik, fonksiyonel ve estetik özellikler dikkate alınarak gerçekleştirildi. İleriye dönük rekonstrüksiyonun baş ve boyun cerrahisinde önemli bir yere sahip olduğuna inanmaktayız.
\end{abstract}

Anahtar Kelimeler: Abbe flebi, köpek ısırığı, radyal ön kol flebi, perioral rekonstrüksiyon.

\section{Abstract}

Animal bites to the face can cause serious defects. In select cases when the avulsed part has been carefully preserved and brought-in with the patient, replantation may be the best solution. In other cases, few strategies are present. The classical "watchful waiting" strategy to treat such patients could be described as letting the wound to heal and only then, initiate reconstruction. Wound scarring and patient's psychological disturbance due to prolonged rehabilitation are its biggest disadvantages. However, a proactive method with reconstruction initiated early during the convalescent phase, can result in faster rehabilitation. Herein, we present detailed description of a successful early reconstruction of the perioral area in a teenage girl following a dog bite; the reconstruction encompassing the anatomical, functional and aesthetic spectrum. Thus, we believe, proactive strategy has a huge potential in the modern era o reconstructive head and neck surgery.

Keywords: Abbe flap, Dog bite, Radial forearm free flap, perioral reconstruction.

ORCID

Kamil Firudinovich Abdullaev

https://orcid.org/0000-0001-5984-5049

\section{INTRODUCTION}

Facial defects, consequent to animal attacks, are not uncommon in reconstructive surgery of head and neck $(1,2)$. When facial segments are avulsed, best results can be achieved with tissue replantation (3). However, in cases devoid of the amputated segment, an ability to combine other reconstructive options and proper planning become particularly significant. Traditionally, a "watchful waiting" approach is used in cases with bitten defects, because of infection risk. Modern infection control measures, as well as the refinements in plastic surgery techniques, allow us to begin reconstructive efforts quite early during the rehabilitation phase, what can be defined as a proactive approach. Here, surgery can be guided by the principles of "The New Reconstructive ladder", according to which complex methods could be chosen if they provide optimal aesthetic and functional outcome (4).

In the following case, we hope to demonstrate a clear example of early reconstructive planning and implementation in a teenager with a defect of the cheek, upper lip and loss of corner of mouth after a dog bite. Even though, the reconstructive techniques employed are well known to plastic surgeons, we assume that a detailed analysis can be valuable alike to the enthusiast novice or a veteran specialist. 


\section{CASE REPORT}

In July 2017, an apparently healthy, 17 years old female, suffered a bite from an unfamiliar dog (Grade IVa (5)). The wound was primarily managed at a nearby children's hospital with antibacterial, anti-tetanus, anti-rabies lg and additional supportive therapy. The next day she was transferred to the department of oral and maxillofacial surgery. A thorough examination revealed: Loss of the right half of the upper lip extending almost up to the philtrum, a deep defect in the right cheek with complete loss of the right corner of mouth. The remnants of right buccal mucosa had been sutured to cover the wound surface of the defect and wounds in the submental area had been sutured by previous team (Figure 1).

\section{First procedure:}

A reconstruction plan as per the following principles was made:

- anatomy - to restore the lost facial units by using authentic tissues

- function - to restore a mouth corner suspension for avoid postoperative drooling

- aesthetics - to provide an acceptable appearance First, thorough debridement of wound margins has been performed to minimize the risk of infection. To restore the buccal mucosa, its remnant parts had been

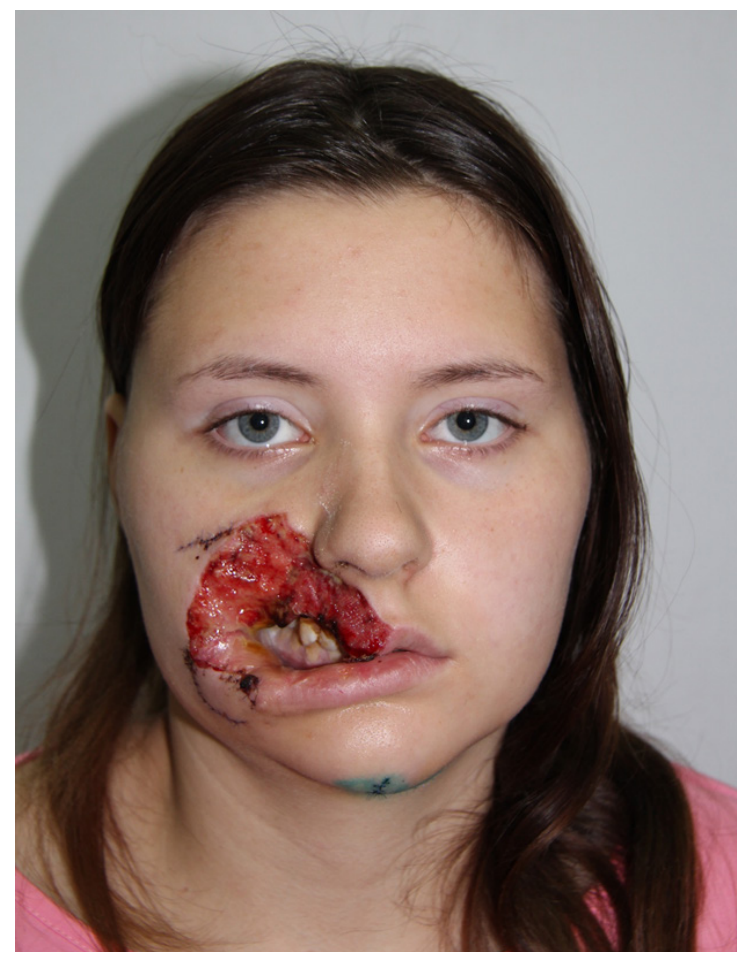

Figure 1. The initial defect

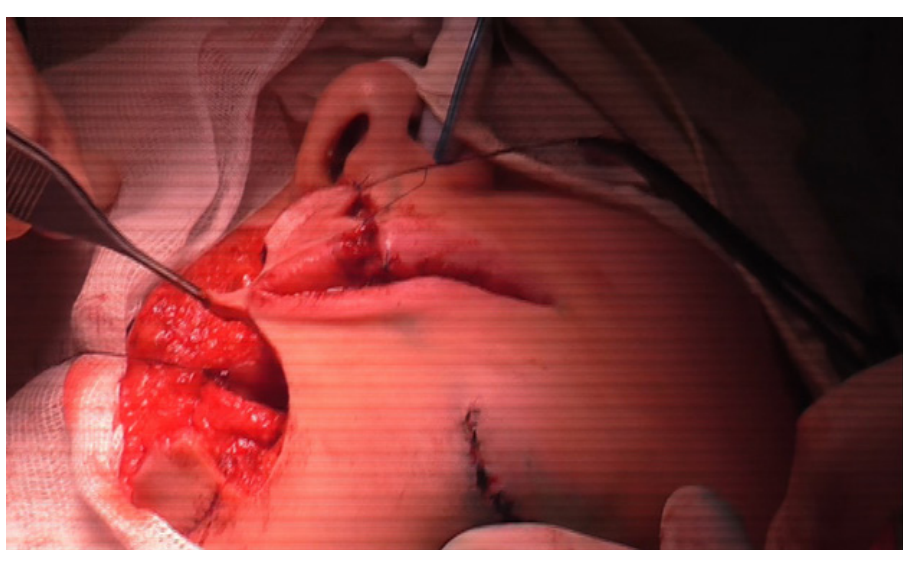

Figure 2. Deepithelized triangular skin island (in forceps) prepared for fixation of static sling

mobilized and then used with local mucosal flaps. An Abbe-Estlander flap has been used to reconstruct the corner of a mouth and half of an upper lip. Since mucosal part of upper lip was intact, Abbe-Estlander flap was planned only in musculocutaneous fashion. The integrity of the right Stenson's duct was verified at this step and found to be intact. The cutaneous layer and volume of the cheek have been restored

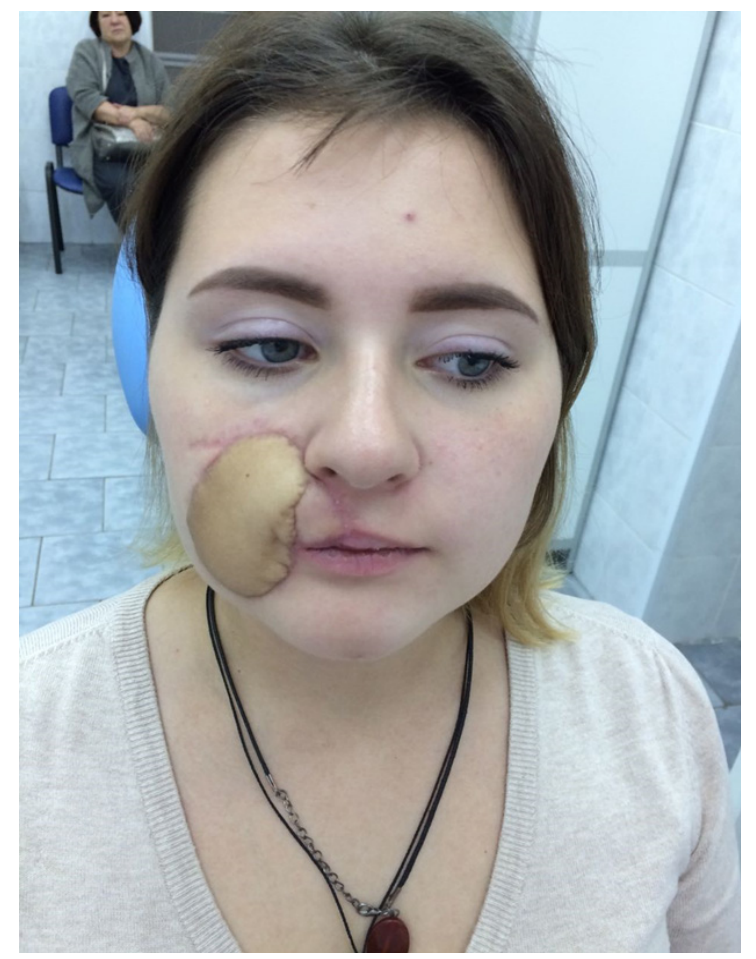

Figure 3. 2 weeks after first operation 


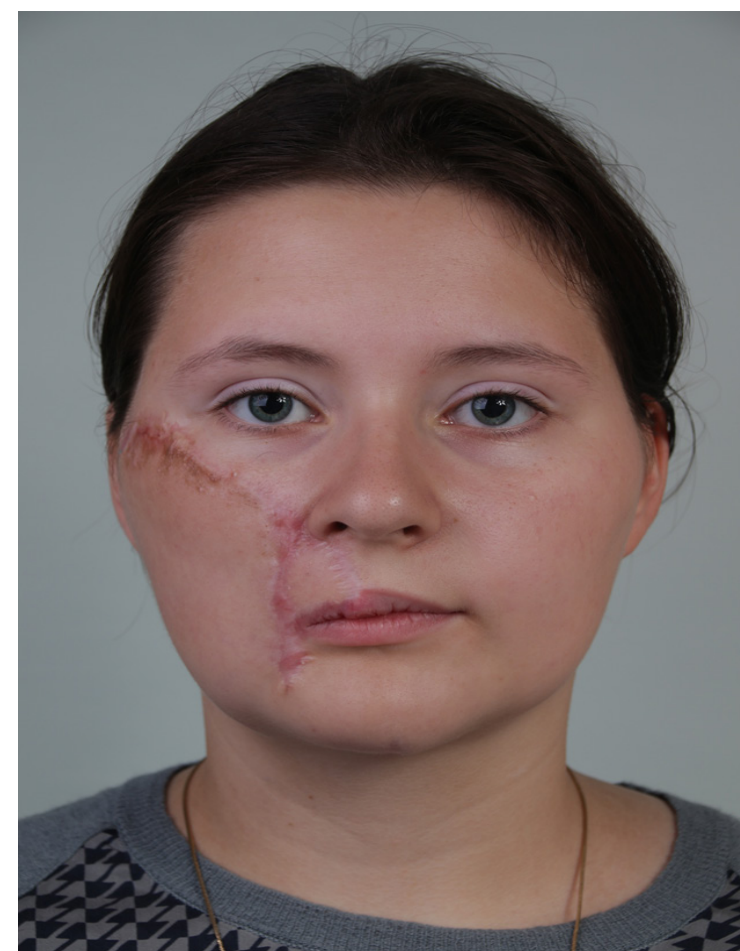

Figure 4. 1 month after second operation

with free radial forearm flap. The flap has been harvested in adipocutaneous fashion, while fascia and cutaneous nerves were preserved. To reduce the risk of complications, it was decided to locate an anastomotic site on the distance from the defect, so facial artery and concomitant vein have been dissected through the submandibular approach and a wide tunnel to the defect has been dissected. The donor wound at the forearm was closed with a fullthickness skin graft from the thigh. By manipulations mentioned above, the lost and damaged structures have been reconstructed in accordance with anatomy.

To restore the function of oral sphincter and to prevent postoperative drooling, a static suspension of the newly formed corner of a mouth was performed using a deep temporal fascia graft. One end of the sling has been fixed to the zygomatic bone with a mini-screw, when the other end was sutured to a deepithelized triangular skin island, specially formed at the Abbe-Estlander flap. The triangular skin flap allowed to provide a secure suspension of the neocommissure without risk of compromising blood circulation of the Abbe-Estlander flap by stitches. The static sling has been fixed under control of mouth opening (Figure 2 ).

Postoperatively, mouth opening was fully restored within two weeks. No functional disorders noted at forearm and temporal regions. The left cheek contour was also restored. Evidently, skin color and texture difference became the patient's prime concern (Figure 3).

\section{Second procedure:}

In Jan 2018, six months later, a revision surgery was performed. The transplanted radial forearm flap was deepithelized and a cervico-facial advancement flap was used to resurface the area resulting in a much natural skin texture and color match with the surrounding area. Thus, an acceptable aesthetic result has been achieved (Figure 4).

\section{DISCUSSION}

Replantation procedure gives the best results after avulsion, due to the unique nature of facial tissues. Its straightforward approach is another advantage while secondary reconstructive methods always provide more than one option to choose in a particular situation. Vermillion is one of the unique components of lips, that's why the Abbe - Estlander flap has been chosen for the upper lip reconstruction. At the same time, this technique allowed us to form a mouth corner. Triangular skin island was very useful for fixation of a static sling because suturing directly through the mouth corner might cause damaging of the flap vessels and result in flap necrosis. The most appropriate flap for cheek reconstruction could be harvested from a submental area, due to its tissue similarity [6]. However, in this case, a deep wound in the submental area existed, so the free radial forearm flap has been chosen. Because of the absence of a palmaris longus tendon, it was decided to harvest a temporal fascia for a static sling.

Using a modeled anterolateral free flap could have provided a lesser donor site morbidity due to a possibility to harvest fascia latae (for sling) and primary closure of donor defect $(7,8)$, but we preferred the radial forearm flap because of its reliability and technical simplicity.

In our opinion avoiding of time-frame of living patient with functional and aesthetic defects could be the biggest advantage of a proactive approach. With this case, we hoped to demonstrate in details that well planned and precisely realized reconstruction, performed at the early stage after a bitten injury could provide an optimal outcome, but further studies are needed for exact evaluation of all the advantages and 


\section{risks of the proactive approach.}

Conflict of interest: Authors declare that there is no conflict of interest between the authors of the article.

Financial conflict of interest: Authors declare that they did not receive any financial support in this study.

Address correspondence to: Kamil Firudinovich Abdullaev Mira str, building 6, app. 24, Volgograd city, Russia. 400066 e-mail: drabdullaevkamil@gmail.com

Mobile: +79660275246

\section{REFERENCES}

1. Morgan, JP, Haug RH, Murphy MT. Management of facial dog bite injuries. Journal of Oral and Maxillofacial Surgery 1995;53(4):435-41.

2. Eskitascioglu T, Dogan F, Altiparmak M. Reconstruction of a nasal injury caused by a horse bite: Case Report. Erciyes Medical Journal 2013;33(4):335-40.

3. Jayakumar R, Zachariah JR, Senthilkumar $M$, et al. Composite facial part replantation.Plast Reconstr Surg 2013;131(2):296e-298e.

4. Janis JE, Kwon RK, Attinger CE. The new reconstructive ladder: Modifications to the traditional model. Plast Reconstr Surg 2011;127 Suppl 1:205S-212S.
5. Lackmann G, Draf W, Isselstein G, et al. Surgical treatment of facial dog bite injuries in children. J Cranio-Maxillofacial Surg 1992;20(2):81-6.

6. Pistre V, Pelissier P, Martin D, et al. Ten years of experience with the Submental flap. Plast Reconstr Surg 2001;108(6):1576-81.

7. Huang $\mathrm{W}$, Chen $\mathrm{H}$, Jain $\mathrm{V}$, et al. Reconstruction of throughand-through cheek defects involving the oral commissure, using chimeric flaps from the thigh lateral femoral circumflex system. Plast Reconstr Surg 2002;109(2):433-41.

8. Abdullaev KF, Orlova EV, Yadav MK, et al. Preoperative planning for advanced modelling of anterolateral thigh flaps in the treatment of severe haemifacial atrophy in Parry- Romberg and Goldenhar syndrome. JPRAS Open 2018;16:36-49. 